\title{
Interleukin-23 Subunit Alpha
}

National Cancer Institute

\section{Source}

National Cancer Institute. Interleukin-23 Subunit Alpha. NCI Thesaurus. Code C61152.

Interleukin-23 subunit alpha (189 aa, $21 \mathrm{kDa}$ ) is encoded by the human IL23A gene. This protein plays a role in cytokine activity and immune response. 